\title{
SPATIAL PLANNING AS A TOOL FOR EFFECTIVE NATURE CONSERVATION: A CONCEPTUAL FRAMEWORK FOR TURKEY'S SPATIAL PLANNING SYSTEM
}

\author{
ESRA YAZICI GÖKMEN ${ }^{1}$, NURAN ZEREN GÜLERSOY ${ }^{2}$ \\ ${ }^{l}$ Graduate School of Science Engineering and Technology, Istanbul Technical University, \\ Ayază̆a Campus, Maslak, İstanbul \\ ${ }^{2}$ Department of Urban Planning, Faculty of Architecture, Istanbul Technical University, \\ Taşkışla Campus, Taşkışla Avenue No: 2, Şişli, Istanbul
}

Received: $17^{\text {th }}$ January 2018, Accepted: $23^{\text {th }}$ April 2018

\begin{abstract}
Protected areas can be parts of larger ecosystems, and land use changes in the unprotected part of the ecosystems may threaten the biological diversity by affecting the ecological processes. The relationship between protected areas and their surroundings has been influential in understanding the role of spatial planning in nature conservation. This article focuses on the problem that Turkey's protected areas are vulnerable to pressure and threats caused by land use changes. Spatial planning serving as a bridge between nature conservation and land use is the solution for effective nature conservation in Turkey. Thereby, the aim of this article is to develop a conceptual framework which offers spatial planning as an effective tool to bridge the gap between land use change and nature conservation. In this context, first literature review is conducted, and systematic conservation planning, evidence-based conservation planning, bioregional planning and national system planning are presented as effective planning methods in nature conservation. In addition to literature review, official national statistics and Convention on Biological Diversity's country reports are utilized to shed light on Turkey's current state. Finally, a conceptual framework is defined, the main differences with the current situation are revealed. The results indicate that an effective planning system for Turkey's protected areas incorporates a holistic, target-oriented system defining the spatial planning process for protected areas. The spatial planning system to be developed in this context is also used by decision-makers in evaluating the ecological effectiveness of existing plans.
\end{abstract}

Keywords: Nature conservation, natural protected areas, ecological planning, biological diversity

\section{INTRODUCTION}

Protected areas are the most common instrument to conserve biological diversity and ecosystem services (Cardinale et al., 2012). According to the Protected Planet Report 2016, protected areas cover approximately $15 \%$ of the world's terrestrial and inland waters, $10 \%$ of the coastal and marine areas, and approximately $4 \%$ of the global ocean (UNEP-WCMC and IUCN, 2016). It is expected that protected area coverage will increase in alignment with 
Yzici Gökmen E., Zeren Gülersoy N.: Spatial planning as a tool for effective nature conservation: A conceptual framework for Turkey's spatial planning system

Aichi Biodiversity Targets (Secretariat of the Convention on Biological Diversity, 2010). Despite the increase in protected area number and coverage, biological diversity loss and global species extinction have reached unprecedented rates in history (Pimm et al., 2014). This exceptionally rapid loss of biological diversity indicates that a sixth mass extinction is already underway (Ceballos et al., 2015). One of the main reason of this human-induced species losses is that protected areas can be parts of larger ecosystems, and land use change occurring outside of protected areas may threaten the biological diversity by affecting the ecological processes (Hansen \& DeFries, 2007).

The relationship between protected areas and their surroundings has been better understood with two fundamental theories which are Island Biogeography Theory and Metapopulation Theory. In his seminal work in 2001, Hanski developed a new theory by synthesising the Island Biogeography Theory developed by MacArthur \& Wilson (1967) and the Metapopulation Theory developed by Levins (1969). Accordingly, colonisation and extinction in the Metapopulation Theory vary depending on the area and location of the divided parts of the land. Thus, the formation of site-specific species can be estimated (Hanski, 2001). The synthesis of the theory of Island Biogeography with the theory of Metapopulation helped reveal the strong interlinkages between ecology and land use change.

Understanding how land use change affects ecological processes adversely has been influential in developing nature conservation approaches towards protected areas. In the 1970 s, the proportion of terrestrial nature conservation areas increased rapidly, and countries began to establish protected area networks in an attempt to save species and ecosystems from land use changes (Watson, 2014). After the 1990s, ecological-based methodologies have been adopted in nature conservation, especially under the influence of sustainable development approaches. During this period, the protection of the links between protected areas and the establishment of protected areas networks have come to the fore. Ecological corridor/network practices have emerged to connect protected areas to each other and to allow the movement of species between them (Palomo et al., 2014).

Since the 2000s, landscape approach has gained prominence as ecological networks failed to efficiently preserve biological diversity. The landscape approach, proposed during the Fifth World Parks Congress (Benefits beyond boundaries) held in Durban, South Africa in 2003, was adopted as a conservation approach that took into account the surroundings of protected areas. According to this approach, the area around the protected areas should be managed together with the protected area so that conservation goals can be achieved (Hansen $\&$ DeFries, 2007). In the scientific context, landscape approach commonly includes approaches that conceptualise and evaluate the relations and interactions between communities and their surroundings. Among such approaches are the Resilience Approach (Lin, 2011), the Socio-Ecological System Analysis (Glaser et al., 2008), the Driving Forces-Actors Analysis (Hersperger et al., 2010), Integrative Planning and Modeling (Castella et al., 2014) and Sustainable Land Management (Schwilch et al., 2012). Specific aspects of landscape approach such as the ability to find solutions to Problems in sectoral approaches (Sayer et al., 2013), and the ability to understand the interactions between local communities and their environments (DeFries et al., 2010) place it in a position of utmost significance on the sustainable development agenda (Bürgi et al., 2017).

Recognizing the socio-ecological collapse on a global scale, the United Nations Conference on Sustainable Development (Rio+20) held in 2012, introduced the Sustainable Development Goals, which were adopted by the United Nations General Assembly in 2015 (United Nations, 2015). Both Millennium Development Goals and Sustainable Development Goals include coverage of protected areas as a development indicator because there is a significant relationship between the level of development and coverage of protected areas 
(Opršal et al., 2018). Many global issues addressed in the Sustainable Development Goals require integrative approaches such as integrative socio-ecological system analysis, and landscape approach (Reed et al., 2016).

The previous researchers examining the effects of the land use change on protected areas were mostly focused on single land use. Although these studies were important in understanding land use impacts on protected areas, they lacked a holistic perspective of land use change evaluation at the landscape level (Wilson et al., 2014). However, for effective nature conservation, higher level spatial planning should be an indispensable tool, particularly for a developing country like Turkey where economic development is almost always prioritized over nature conservation.

In Turkey, ecologically insufficient spatial plans threat protected areas and country's unique biological diversity. According to The National Biological Diversity Strategy and Action Plan (Ministry of Environment and Forestry, 2007) and Fifth National Report (Ministry of Forestry and Water Affairs, 2014) main threats to Turkey's biological diversity are related to land use. This article focuses on the problem that Turkey's protected areas are vulnerable to pressure and threats caused by land use changes. As a developing country with significant biological diversity, in Turkey, spatial planning serving as a bridge between nature conservation and land use, may be the solution for effective nature conservation. Thereby, this article aims to develop a conceptual framework which offers spatial planning as an effective tool to bridge the gap between land use change and nature conservation. In this context, the main research question asks how a spatial planning system can be effective in nature conservation.

\section{MATERIALS AND METHODS}

Turkey's unique geographical location marks it out as one of the countries with rich biological diversity. That is, the country uniquely sits within a transition zone between three biogeographic regions which are Anatolian, Mediterranean and the Black Sea region. Ecosystems in the country range from mountains to wetlands or coastal and marine ecosystems (Fig. 1). Almost all of the country's territory is covered by the Caucasus, Irano-Anatolian, and Mediterranean biodiversity hotspots, which constitute three of the 36 hotspots in the world (Çağatay et al., 2013). $75 \%$ of European plant species are found in Turkey, to approximately one-third of which it is endemic (Çepel, 2003; Türkeş, 2015). Turkey's fauna biological diversity is also rich compared to Europe; Anatolia is home to 1.5 times more animal species than Europe (Çepel, 2003; Türkeş, 2015). Despite its significance, is paid little attention in the country - a fact illustrated by Turkey's $177^{\text {th }}$ rank out of 180 countries in biological diversity and habitat conservation, according to Environmental Performance Index 2016 (Hsu et al., 2016).

Turkey's attempts to protect its biological diversity began in the mid-twentieth century. While across the globe nature protection had shifted toward holistic approaches, Turkey designated its first national park in 1958. Besides in Turkey, due to the adoption of economic development approach, legislative gaps in spatial planning, and dysfunctional implementation phases such as monitoring and evaluation, the effectiveness of spatial planning in nature conservation is often weakened. This weakness results in ineffective nature conservation where conservation plans are incapable of achieving their goals. To illustrate, only $47 \%$ of the management plans for protected forest areas met their conservation objectives between the dates 2000 and 2003 (Kuvan et al., 2011). As a result, despite national legislation and international agreements, spatial plans to date have not been sufficient to stem the increasing human pressures on the country's nature. 
Yzici Gökmen E., Zeren Gülersoy N.: Spatial planning as a tool for effective nature conservation: A conceptual framework for Turkey's spatial planning system

\section{Fig. 1: Different Ecosystems in Turkey:}

(a) Bencik Bay, Mediterranean Region; (b) Karagöl-Sahara National Park, East Black Sea Region; (c) Dalyan İztuzu beach and wetland, Mediterranean Region; (d) Göksu delta Ramsar site, Mediterranean Region; (e) Munzur Valley, East Anatolia Region; (f) East Black Sea Mountains, Black Sea Region (Ministry of Environment and Urbanism, Ministry of Forestry and Water Affaires)

(a)

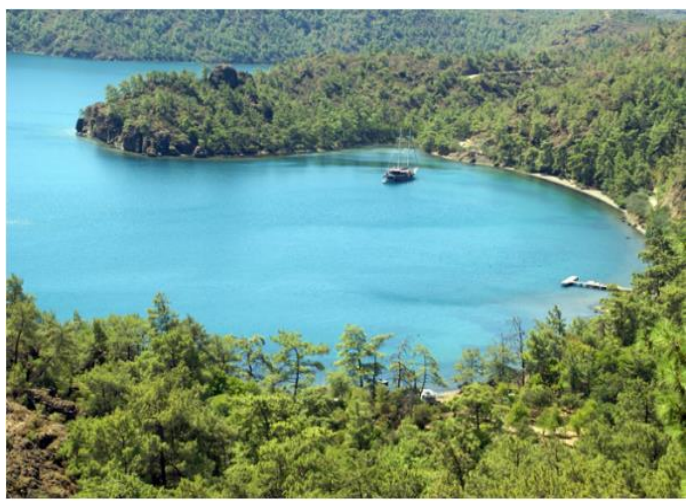

(c)
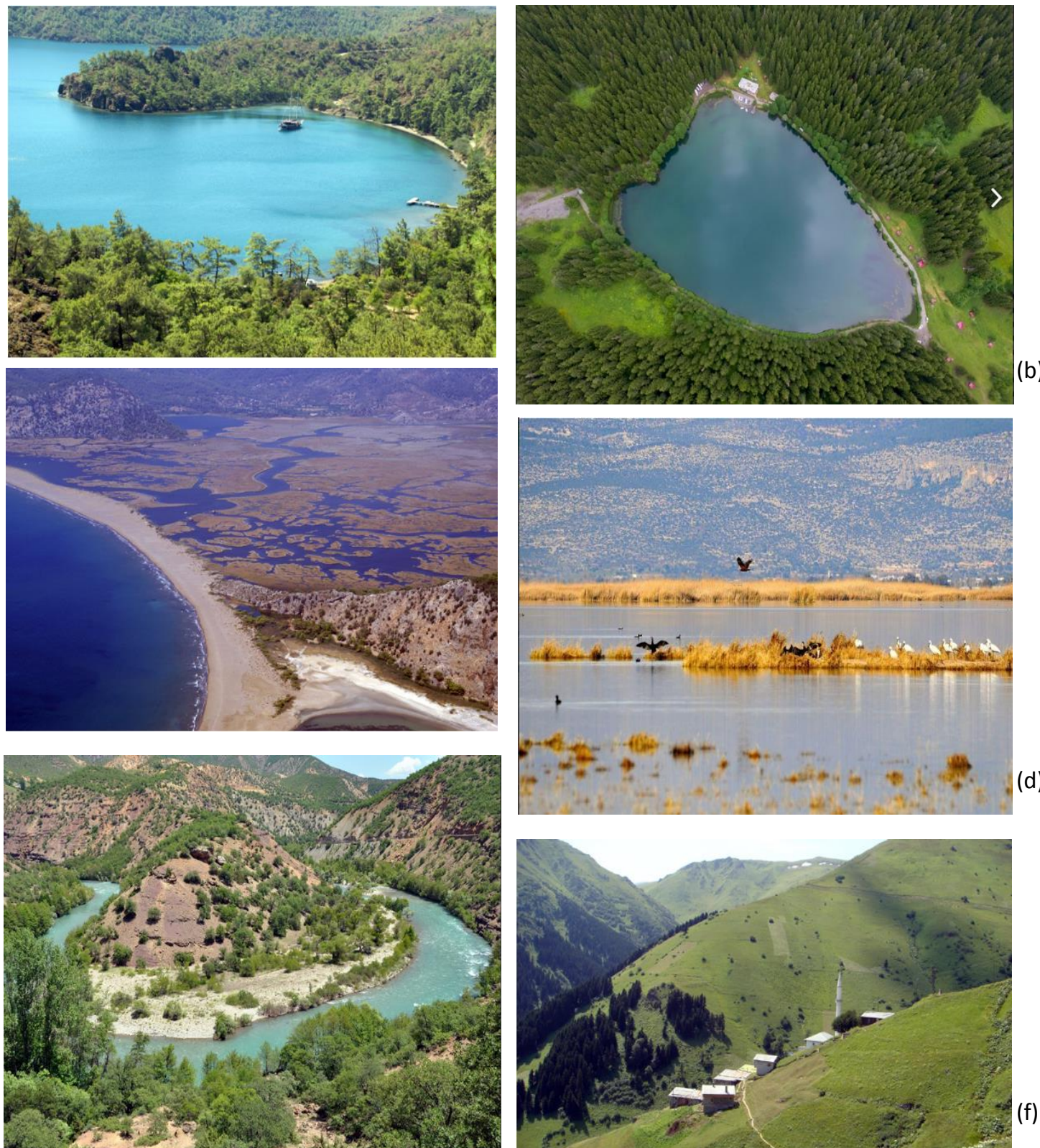
Within the aim of this article, first literature review that is related to the relationship between nature conservation and land use is conducted. According to the literature review, Systematic Conservation Planning, Evidence-Based Conservation Planning, Bioregional Planning and National System Planning are presented as effective planning methods in nature conservation. In addition to the literature review, main resources about Turkey's current situation are official national statistics and Convention on Biological Diversity's Country Reports. Finally, the spatial planning process for effective nature conservation is defined, the main differences with the current situation are revealed, and further thoughts and recommendations are presented to open avenues for the improvement of spatial planning effectiveness in nature conservation.

\section{EFFECTIVE CONSERVATION PLANNING METHODS IN PROTECTED AREAS}

To define the general principles of the spatial planning system which ensures sustainability of ecological functions, creates ecological corridors linking natural protected areas to each other and their surroundings and considers ecological consequences of land use decisions, planning methods for nature conservation are evaluated. Systematic conservation planning, evidence-based conservation planning, bioregional planning and national system planning are selected as effective planning methods.

\section{Systematic Conservation Planning}

Systematic Conservation Planning has been an effective approach protecting biological diversity at global and national scales (Wu et al., 2014). Systematic conservation planning is primarily important for prioritising conservation areas at large scale, and for carrying out detailed studies at the local level (Bosso et al., 2013).

The process of Systematic Conservation Planning was established by Margules and Pressey (2000), then developed by Groves et al. (2002). Systematic Conservation Planning refers to the process of developing a conservation management system whose conservation objectives are defined, in which the whole biological diversity is represented permanently and which is not just limited to the conserved areas (Sarkar \& Illoldi-Rangel, 2010). A conservation system is planned for the area by using the biological and socio-economic data. Systematic Conservation Planning also allows for participatory planning, to prioritise areas according to their biological diversity and to cooperate in the implementation of conservation strategies, decisions and actions (Kukkala \& Moilanen, 2013). After analyses and stakeholder meetings are held, important areas for biological diversity should be identified, and their conservation prioritisation should be clarified.

Pressey \& Bottrill (2009) developed an eleven step process for Systematic Conservation Planning (Fig. 2). According to this process, Systematic Conservation Planning starts with scoping and costing the planning process. When stakeholders are identified and involved (Step 2), the process enables their contribution till the end. At the sixth step which is collecting data on biological diversity and other natural features, boundaries of the planning area may be redetermined. Another feedback is possible between the last step which is maintaining and monitoring conservation areas and a ninth step which is selecting additional conservation areas.

In Systematic Conservation Planning, not only the data of species is used, but also other elements of biological diversity such as unity of life, ecosystems, ecological and evolutionary processes are included in evaluation as much as possible. The inclusion of these diverse elements of biological diversity in the planning process reveals the representation degree of 
Yzici Gökmen E., Zeren Gülersoy N.: Spatial planning as a tool for effective nature conservation: A conceptual framework for Turkey's spatial planning system

the planning area, which is one of the most significant criteria for the conservation systems (Kukkala \& Moilanen, 2013).

Systematic Conservation Planning studies are also carried out in Turkey. For instance, between 2004 and 2008, the former Ministry of Environment and Forestry conducted the Coastal Aegean Priority Conservation Areas study through the Biodiversity Monitoring Unit (BMU), established within the scope of GEF-II Biological Diversity and Natural Resource Management Project. In this study, experts from the Ministry conducted both the data collection and analysis processes. The priority conservation areas were determined within the process (Ün et al., 2009). Other Systematic Conservation Planning activities include the Anatolian Cross Biodiversity Project, the Mediterranean Priority Forest Areas Project, and the Black Sea Region Systematic Conservation Planning Project, all coordinated by the Nature Conservation Center (Turak et al., 2011). However, the integration of these projects into regional planning has not yet been achieved. Despite allowing the nature conservation area to be addressed at national or regional levels, Systematic Conservation Planning is inadequate in integrating nature conservation into spatial planning systems in Turkey.

Fig. 2: Process of the Systematic Conservation Planning (Pressey \& Bottrill, 2009)

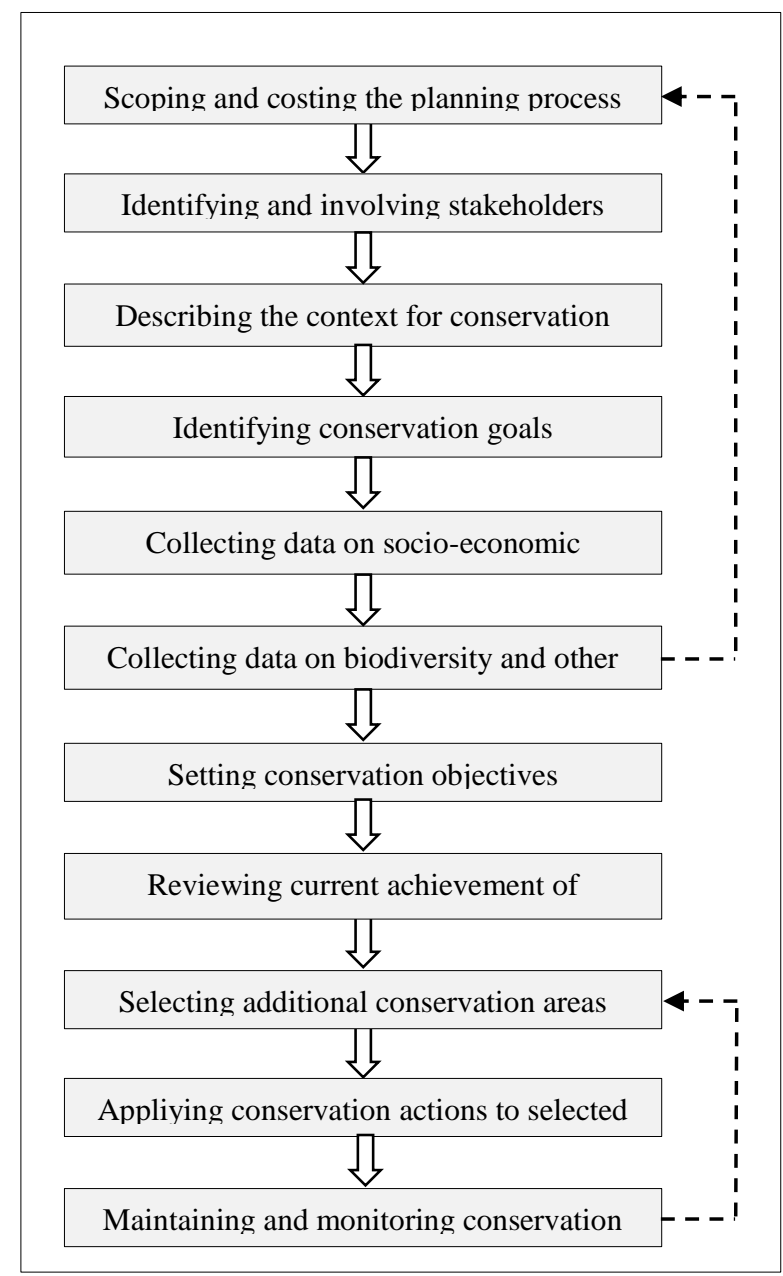




\section{Evidence-Based Conservation Planning}

While Systematic Conservation Planning helps to address protected areas both at regional and national levels, Evidence-Based Conservation Planning uses scientific data in nature conservation process. Evidence-Based Conservation aims to form a scientific and experimental basis for the conservation policies and plans. It also ensures that, based on scientific evidence, objective decisions are made during planning and implementation processes (Pullin et al., 2013).

Drawing mainly on the methods used in the fields of medication and public health, Pullin and Knight (2001) devised a framework for Evidence-Based Conservation Planning. According to this research, for Evidence-Based Conservation Planning to be fully actualised, there is a definite necessity for effective mechanisms which will gather scientists and specialists, and strengthen the information flow among them (Pullin \& Knight, 2003).

Evidence-Based Conservation Planning provides a systematic perspective to the conservation planning of protected areas and includes monitoring data as well as scientific data (Fig. 3). The process involving evaluation of evidence delivered to the decision-maker through systematic review starts and proceeds as a generic and adaptable process till the fourth step. At the fourth step which is rational for action, evidence for the action's effectiveness is assessed, and if there is lack of evidence, the evidence is collected.

Sutherland et al. (2004) attributed the common problem of conservation studies to their lack of being based on evidence. To address this problem, they suggested the development of web-based databases for the implementation and the preparation of management plans. During their studies, Pullin \& Stewart (2006), prepared detailed guides for Evidence-Based Conservation Planning. Head (2008) pointed out the difficulties and constraints of the evidence-based approach, suggesting that work should not be based solely on empirical analyses and that the evidence is debatable and diverse.

While scientific data are used in nature conservation processes, the mechanisms for the efficient use of this data by decision makers remain insufficient. Evidence-Based Conservation Planning provides a framework for this issue (Ekroos et al., 2017). 
Yzici Gökmen E., Zeren Gülersoy N.: Spatial planning as a tool for effective nature conservation: A conceptual framework for Turkey's spatial planning system

Fig. 3: Model of Evidence-Based Conservation Planning (Pullin \& Knight, 2003)

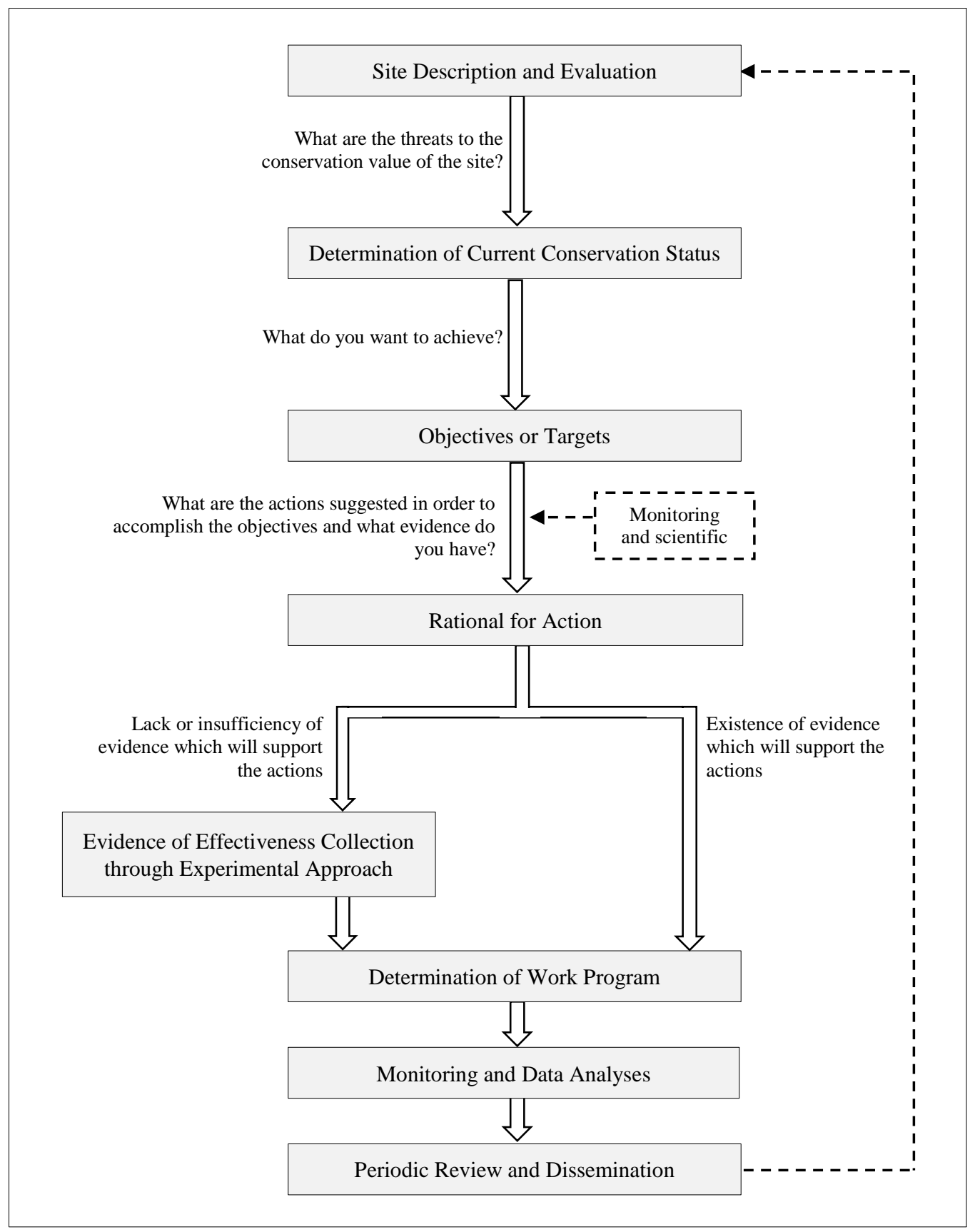




\section{Bioregional Planning}

Unlike Systematic Conservation Planning or Evidence-Based Conservation Planning, Bioregional Planning enables conservation actions for transboundary areas. The bioregion refers to one or more geographical areas that contain interconnected ecosystems. Characterized by landforms, vegetation, and cultural and historical values, it is a part of biomes and can harbour river basins, valleys or forests, and wetlands (Miller, 1996). This approach has been used in the development of the protected area matrix from the IUCN classification of nature conservation areas (Dudley, 2008). IUCN classification consists of six categories. The protected areas in categories I and II have surrounded with the areas in categories IV, V and VI - which may be considered as buffer zones-, and they are associated with other protected areas and their buffer zones via biological corridors (Miller, 1996). For an effective conservation, all these areas should be addressed together.

According to Bioregional Planning, an ecological network is defined as a system of reserves of natural sites and reciprocal relations of these areas (Jongman, 2004). Such a system usually consists of strictly protected areas surrounded by buffer zones and ecological corridors linking all these areas (Doko \& Chen, 2012) (Fig. 3). Natura 2000 Network implemented within the European Union is an example of ecological networks. However, this network system has been incapable of preventing the biological diversity loss throughout Europe (Davis et al., 2014).

In Bioregional approach, the buffer zones and corridors can be located outside the administrative authority of the protected area. These areas, which are mostly privately owned, require voluntary partnership agreements, partnerships and participatory methods (Cook et al., 2016). As can be seen, the Bioregional approach is not just developed for individual protected areas, but also for areas of national and even international scale. This approach addresses protected areas along with their surroundings and ensures that conservation actions are implemented within as well as outside the protected area (Vilhena \& Antonelli, 2015).

\section{National System Planning For Protected Areas}

While Bioregional Planning integrates protected areas with national strategy and conservation, National System Planning addresses the needs of protected areas pointed out by Bioregional Planning (Davey, 1998). National System Planning is developed as an appropriate method for planning and management of protected areas at the national level, which is integrated into broader land and seascapes (Secretariat of the Convention on Biological Diversity, 2004).

In the light of Millennium Development Goals, Plan of Implementation of the World Summit on Sustainable Development, The Durban Action Plan and $5^{\text {th }}$ World Parks Congress's Action Plan, the Convention on Biological Diversity Program of Work on Protected Areas was adopted at the $7^{\text {th. }}$ Conference of the Parties, in 2004. Program of Work is particularly crucial as it is one of the most comprehensive programs that include commitments prepared at the international level. The overall purpose of the Program of Work is to support the establishment and maintenance of terrestrial and marine areas through comprehensive, effectively managed, and ecologically representative national and regional systems of protected areas, thereby to contribute to the achievement of the three objectives of the Convention through a global network (Secretariat of the Convention on Biological Diversity, 2004; Dudley et al., 2005). The need to establish a protected area system is thus recognised not only at the national level but also at the international level. 
Yzici Gökmen E., Zeren Gülersoy N.: Spatial planning as a tool for effective nature conservation: A conceptual framework for Turkey's spatial planning system

While developing national system plans, it is also necessary to identify the links between the site and system planning (Fig. 4). There are fundamental differences between National System Planning and Management Planning At The Site Level. National System Plans, unlike Site Management Plans, examine the country as a whole, provide coordination with other plans and between different units of a national system and enables the formation of a coherent system. For instance, National System Plan for the British Virgin Islands was suggested to include system development strategies and system guidelines. System development strategies are conducting system level activities. On the other hand, system guidelines should provide detailed information for management plans at the site level.

Fig. 4: National System and Site Management Plans for Protected Areas (Gardner, 2002)

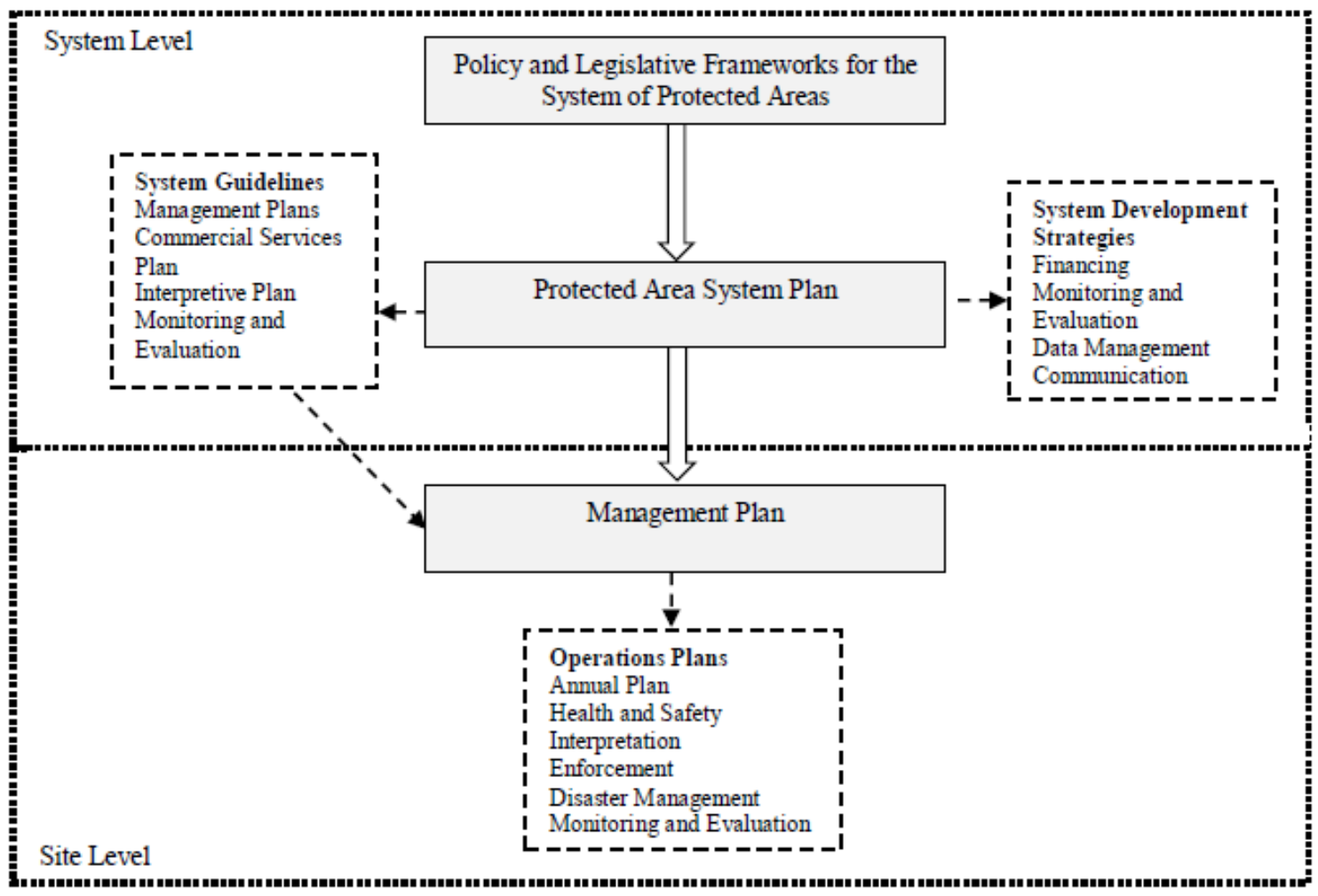

Natural protected areas conservation planning in Turkey

In Turkey, natural protected areas are designated under national legislation and international conventions to which Turkey is a party (Table 1). Internationally designated areas in Turkey consist of Biosphere Reserves, Ramsar Sites and World Heritage Sites. There are 17 World Heritage sites in Turkey, but only two of them are cultural and natural mixed sites. Nationally designated natural areas are divided into 13 different types which are nature conservation areas, nature parks, natural monuments, wildlife conservation areas, protection forests, gene conservation forests, seed stands, seed orchards, city forests, natural 
conservation sites and specially protected areas (General Directorate of Nature Conservation and National Parks, 2016). Natural conservation sites are the most designated areas, whereas specially protected areas cover the largest total area. One of the specially protected areas is the marine protected area. Therefore, the total terrestrial area covered by specially protected areas is approximately 133 million of hectares (General Directorate for Protection of Natural Assets, 2018).

Table 1: Protected Areas in Turkey*

\begin{tabular}{|c|c|c|c|c|}
\hline $\begin{array}{l}\text { Protected Area } \\
\text { Categories }\end{array}$ & $\begin{array}{l}\text { Number } \\
\text { of Areas }\end{array}$ & $\begin{array}{c}\text { Area } \\
\text { Covered } \\
\text { (Hectare) } \\
\end{array}$ & $\begin{array}{c}\text { Responsible } \\
\text { Authority }\end{array}$ & Plans \\
\hline \multicolumn{5}{|l|}{ International } \\
\hline Ramsar Sites & 14 & 184.487 & \multirow{3}{*}{$\begin{array}{l}\text { Ministry of Forestry } \\
\text { and Water Affairs } \\
\text { Ministry of Culture } \\
\text { and Tourism }\end{array}$} & Management plan \\
\hline Biosphere Reserves & 1 & 25.395 & & Management plan \\
\hline World heritage sites & 17 & $16.594,177$ & & Management plan \\
\hline \multicolumn{5}{|l|}{ National } \\
\hline National parks & 42 & 845.814 & \multirow{11}{*}{$\begin{array}{l}\text { Ministry of Forestry } \\
\text { and Water Affairs }\end{array}$} & $\begin{array}{l}\text { Long-term } \\
\text { development plan }\end{array}$ \\
\hline Nature conservation areas & 30 & 47.244 & & \multirow{10}{*}{$\begin{array}{l}\text { Management and } \\
\text { development plans }\end{array}$} \\
\hline Nature parks & 209 & 99.378 & & \\
\hline Wetlands & 38 & 469.830 & & \\
\hline Nature monuments & 111 & 7.142 & & \\
\hline $\begin{array}{l}\text { Wildlife conservation } \\
\text { areas }\end{array}$ & 81 & 1.189 .293 & & \\
\hline Protection forests & 55 & 251.548 & & \\
\hline Gene conservation forests & 295 & 39.732 & & \\
\hline Seed stands & 330 & 43.857 & & \\
\hline Seed orchards & 187 & $1.441,8$ & & \\
\hline City forests & 145 & 10.550 & & \\
\hline Natural conservation sites & 2398 & 2.085 .099 & Ministry of & Conservation plan \\
\hline Specially protected areas & 16 & 2.458 .749 & $\begin{array}{l}\text { Environment and } \\
\text { Urbanism }\end{array}$ & Management plan \\
\hline
\end{tabular}

*Compiled from the data of UNESCO, Ministry of Forestry and Water Affairs, Ministry of

Environment and Urbanism and Ministry of Culture and Tourism, 2018

Recently, Turkey's protected area coverage ratio has just reached $7.24 \%$ of the country (Fig. 5). According to the Aichi Targets, which were adopted under the Convention on Biological Diversity, by 2020 at least $17 \%$ of Turkey's terrestrial and inland water, and $10 \%$ of country's coastal and marine areas, especially areas of particular importance for biological diversity and ecosystem services, are conserved. Those areas should also be protected by efficiently and equitably managed, ecologically representative and well-connected systems and other effective area-based conservation measures, and integrated into the broader landscapes and seascapes (Secretariat of the Convention on Biological Diversity, 2010). However, in Turkey, natural protected areas system is still missing. 
Yzici Gökmen E., Zeren Gülersoy N.: Spatial planning as a tool for effective nature conservation: A conceptual framework for Turkey's spatial planning system

Fig. 5: Turkey's Natural Protected Areas (Ministry of Forestry and Water Affairs, 2013)

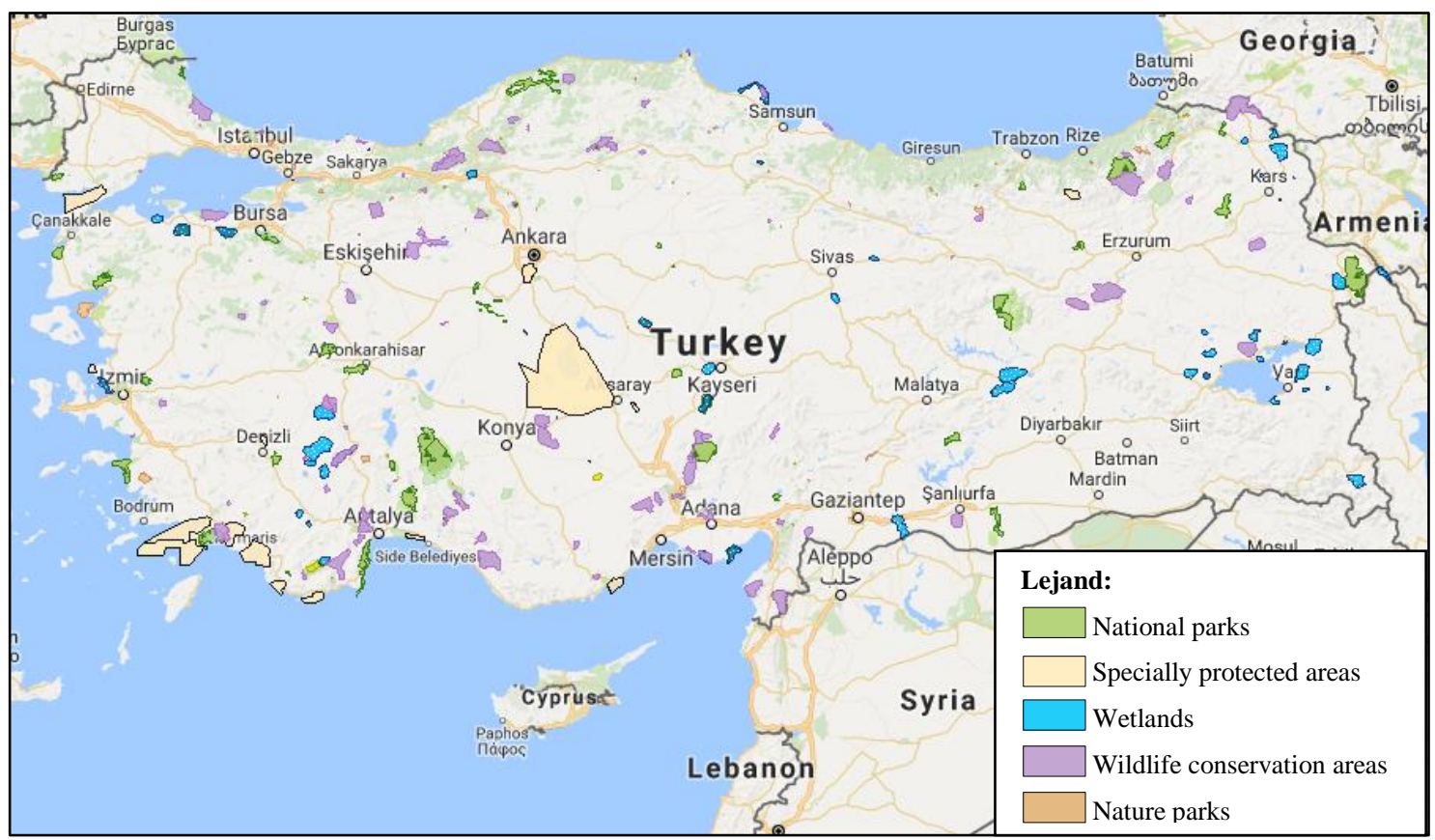

The Ministry of Forestry and Water Affairs and the Ministry of Environment and Urbanism share the responsibility for the conservation and maintenance of natural protected areas. As illustrated in Table 1, two of 16 designation categories are under the Ministry of Environment and Urbanism's planning authority while the rest are under the supervision of Ministry of Forestry and Water Affairs, except World Heritage sites. All of the World Heritage sites, cultural or mixed and cultural protected areas are under the Ministry of Culture and Tourism's authority. Ministries carry out planning studies for protected areas under their responsibilities. Also, the General Directorate for Protection of Natural Assets under the Ministry of Environment and Urbanism is responsible for determining the planning criteria of protected areas (Official Gazette, 2011). Due to the lack of well-established relations between these administrative bodies, planning studies are often performed at local or regional levels in the same area by different institutions.

The General Directorate of Nature Conservation and National Parks under the Ministry of Forestry and Water Affairs is responsible for the preparation of management plans, long-term development plans and conservation plans. Although these plans are prepared to conserve the natural environment, they are insufficient to reach their goals because they are not integrated into higher-level spatial plans or other sectoral plans. As a result of this gap in the planning system, land use changes are among the main threats towards biological diversity. For instance, road project connecting Black Sea plateaux with each other causes habitat fragmentation in the region, which threatens biological diversity in the Anatolian part of Caucasus hotspot, one of the 36 biodiversity hotspots in the world (www.politeknik.org.tr) (Fig. 6). Another project threatening biological diversity is the industrial zone project on the western coast of Black Sea (http://www.karorsan.org.tr/images/Filyos-Vadisi.pdf). The area selected for industrial activities contains wetlands, forests and is one of the stopover habitats 
for migratory birds in Turkey. North Marmara Highway Project in İstanbul is threatening biological diversity in northern forests (www.tema.org.tr). Tourism developments, especially in the coastal areas of Aegean and Mediterranean regions, cause habitat loss and degradation in natural conservation sites (www.yapi.com.tr).

Fig. 6: Examples of Habitat Loss and Fragmentation Due to Land Use Change in Turkey:

(a) Road construction in Black Sea region; (b) Industrial area construction in western Black Sea region;

(c) North Marmara Highway Project in northern İstanbul; (d) Hotel construction in Aegean region

(a)
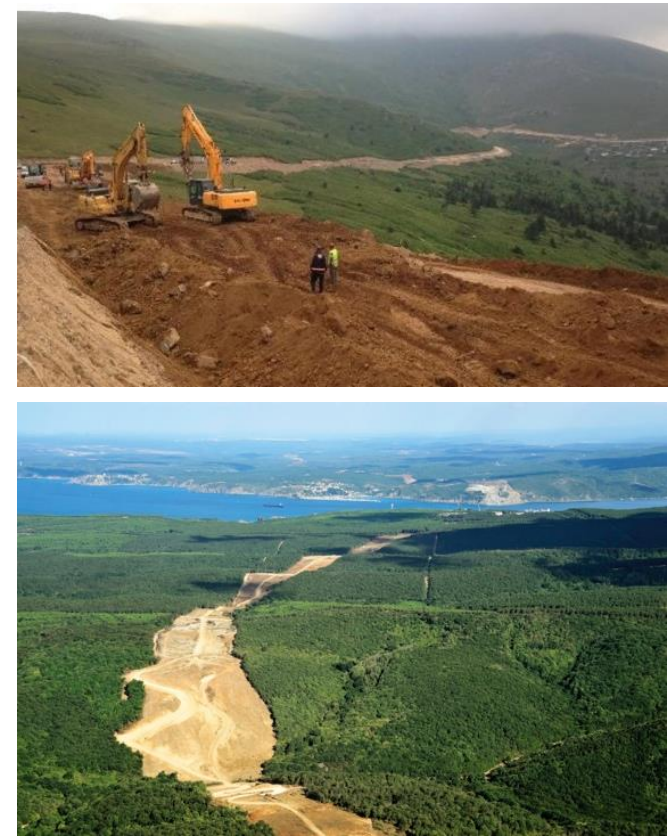

(c) (b)
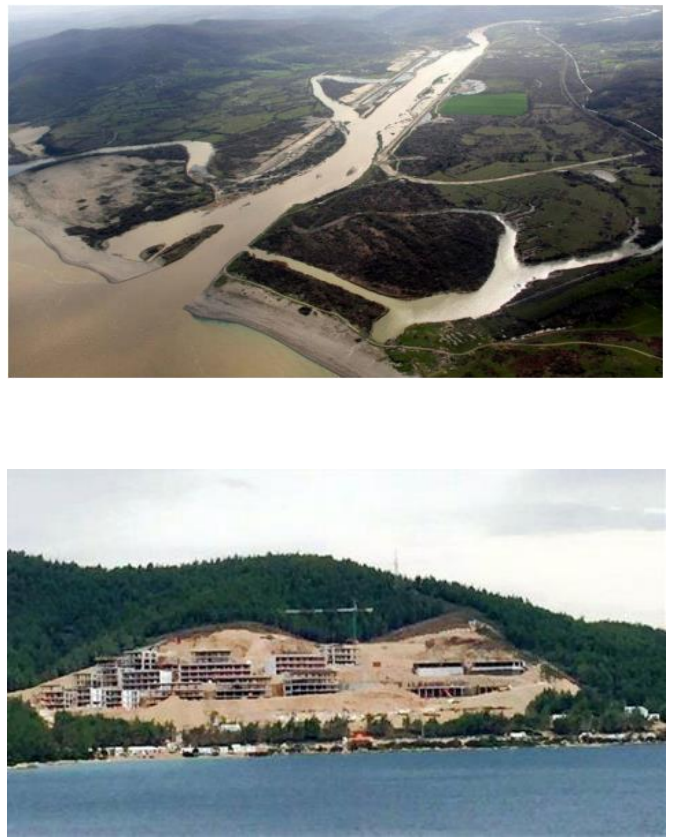

(d)

Figure 7 demonstrates the main steps of the Turkish Planning System. Law on Land Development Planning, and Control and Regulation for Preparing Spatial Plans are the fundamental pieces of legislation that determine the planning process. The planning process unfolds as follows: First, the planning area boundaries are determined. Then, the planning area is defined naturally, socially and economically by acquiring and analyzing the information about existing conditions. After defining the planning area, the planning team gathers related institutions' data and opinions on the planning area. The fourth step includes the development of plan decisions. After the draft plan is approved by the decision makers, the appeal period of 30 days begins. Within 30 days, any person or public body can make a written submission if they have any objection. This is the only step enabling public participation. Finally, during the implementation of the plan, digital databases are updated, and plan amendments or revisions are made if necessary. 
Yzici Gökmen E., Zeren Gülersoy N.: Spatial planning as a tool for effective nature conservation: A conceptual framework for Turkey's spatial planning system

Fig. 7: The Main Steps of Turkish Planning System

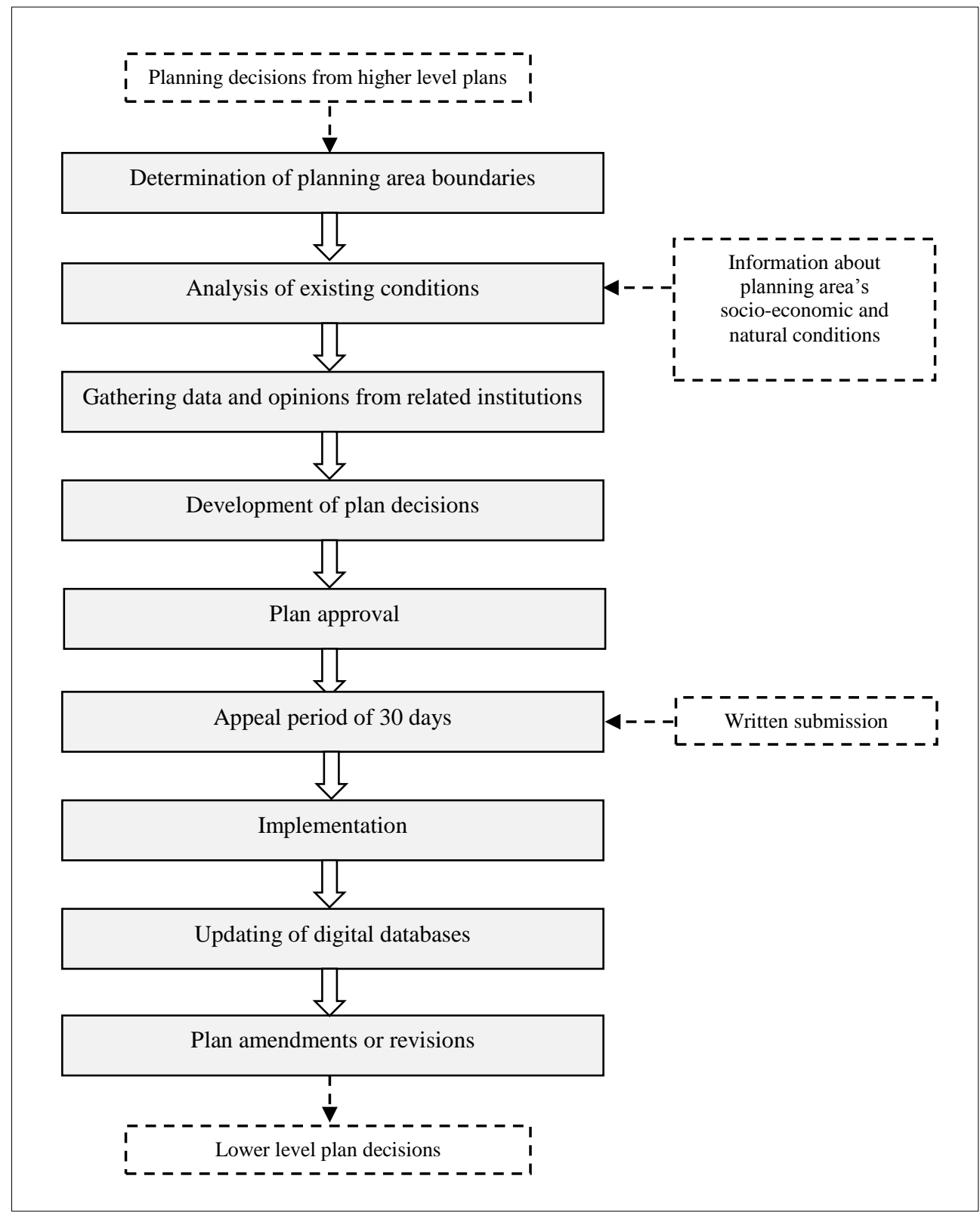

In Turkey, the lack of coordination between spatial planning strategies at national, regional and local levels further undermines the effectiveness of nature conservation. Since planning studies for nature conservation areas are conducted within the protected area, and since national nature conservation strategies and spatial planning studies are not integrated into the protected areas systems, they are mostly unable to save protected areas from anthropogenic threats. Furthermore, current spatial planning process does not include ecological aspects of 
the planning area. Not to integrate all the ecological process and patterns of the planning area within planning process causes habitat loss and degradation which ends up with biological diversity loss. For this reason, there is a need for a spatial planning system that will integrate ecological issues and ecological point of view into spatial planning. To develop such a spatial planning system, an ecologically sustainable and effective spatial decision-making process must first be defined.

\section{A PROPOSAL FOR EFFECTIVE SPATIAL PLANNING PROCESS IN NATURE CONSERVATION IN TURKEY}

For a spatial plan to be effective in nature conservation, a framework including planning steps is developed as a conceptual model for decision-makers, to incorporate ecological sustainability dimension into the spatial planning concept. The framework in this article, limited to the eco-physical dimension, has been developed based on the current Turkish spatial planning system, described in the previous section.

While basic principles of the conceptual framework being developed, planning methods presented in the second section, have been referred. In this context, the planning system is a non-linear process, which defining planning area with all its ecological pattern and process, enabling feedbacks and stakeholder involvement, defining key performance indicators for the monitoring and evaluation.

\section{Determination of Planning Area Boundaries}

The first step of the Effective Planning Process is to determine the boundaries of the planning area (Fig. 8). Spatial planning area should be the watershed unit, as it consists of natural patterns and processes. If natural boundaries are not taken into account while determining planning area boundaries, the effects of land use changes on ecosystems cannot be forecasted.

\section{Analysis of Existing Conditions}

The analysis of existing conditions is divided into two stages, which are the definition of the planning area, and the determination of the stakeholders and public participation methods (Fig. 8). The definition of the planning area is crucial to understand the area's values and the threats it is faced with. Hence, research and analysis should be undertaken on a range of economic, social and environmental subjects to provide a factual base for the plan. This step also includes analyses of the current legislation on protected areas and the evaluation of these analyses (Fig. 8).

An open, transparent and participatory planning process contributes significantly to effective nature conservation and management (Hogl et al., 2012). Especially in developed countries, public participation has a considerable impact on decision-making since it greatly helps to improve the environmental capacity of plan decisions as well as to enhance coordination and implementation. Therefore, the second step of the analysis phase consists of stakeholder identification, stakeholder prioritization, stakeholder evaluation and the determination of the stakeholders' participation method.

The planning team consider the following questions when analysing conditions:

- Are the significance and values of protected areas defined?

- Are the existing and potential threats towards to protected areas defined?

- Is public participation ensured? 
Yzici Gökmen E., Zeren Gülersoy N.: Spatial planning as a tool for effective nature conservation: A conceptual framework for Turkey's spatial planning system

\section{Defining Vision and Mission}

While defining the vision statement, first, stakeholders' perception of the planning area is defined, and then the ideal future of planning area is delineated through a participatory method (Fig. 8). An effective participatory method for the definition of vision consists of the following steps (Gould et al., 2016):

- The definition of the common priority

- The definition of key resources (species, services, habitats and ecological, social and economic indicators)

- The integration of spatial actions with conservation strategies

The mission statement should include the reason for the plan's existence, the service area, the scope and the roles of the plan. It should be constructive, realistic and determined within the framework of the authorities and resources of related decision makers (David et al., 2014).

The planning team consider the following questions when defining the vision and mission:

- Is the ideal future of planning area defined?

- Is the method to achieve the ideal future defined?

\section{Defining Purpose and Objectives}

The definition of purpose and objectives constitutes the fourth step of Effective Planning. For an effective nature conservation, the overall purpose of the plan should be to ensure the sustainability of biotopes and ecosystems. According to this overall purpose, the purpose of the plan should be defined in line with the outcomes of the previous steps. It should also include the reasons why a spatial plan is necessary and specify what it attempts to achieve. Conservation objectives should be clear, measurable, and site-specific (Fig. 8).

\section{Ecosystem-Based Analyses}

Ecosystem-based analyses are comprised of two main steps. The first step involves the identification of ecological networks and general land use demands, and the second step includes the definition of human and biological landscapes (Fig. 8).

The ecological network approach ensures that ecological sustainability is integrated into planning by determining the characteristics of the planning area (Théau et al., 2015). According to this approach, an ecological network is defined as a system of reserves of natural sites and reciprocal relations of these areas (Jongman, 2004). Such a system usually consists of strictly protected areas surrounded by buffer zones and ecological corridors linking all these areas (Doko \& Chen, 2012). In determining ecological networks, first, landscape species are identified. Since landscape species use extensive and ecologically diverse areas and have considerable effects on the structure and function of natural ecosystems, the identification of these species plays a significant role in the protection of the ecological integrity of the planning area. Identifying landscape species includes defining key species diversity, vegetation types and key ecosystems in the area. Then ecological networks in the planning area are determined by defining biotopes, ecosystems and habitats to which landscape species are related.

To identify general land use demands in the planning area, first, anthropogenic land uses and then the human landscape of the planning area should be defined. In their research regarding Central European Mountain Beech Forests, Machar et al. (2017) revealed that historical development is essential for the assessment of the management strategies for forest habitats in protected areas worldwide. Therefore, while identifying general land use demands, past land uses are also determined. After human activities and ecological networks 
have been determined, human and biological landscapes of the planning area are superposed. Finally, sensitive areas to land use change, degraded ecosystems and landscape services are defined.

With the growing popularity of ecological-based approaches, terms such as ecosystem services and landscape services have come to the fore. Landscape services (Peerlings \& Polman, 2004), used for the first time in 2004, were defined by Termorshuizen \& Opdam (2009) systematically and scientifically, to combine landscape ecology and sustainable development concepts. The current definition of landscape services refers to the contribution of landscape and landscape components to overall human well-being (Bastian et al., 2014). Unlike the ecosystem services described in the literature (De Groot et al., 2002), landscape services describe the capacity of services provided by a landscape area (Willemen et al., 2012). This approach can be used particularly for research on spatial dimension, areas with human interaction or participatory landscape planning (Wu, 2013). Furthermore, as Syrbe \& Walz (2012) pointed out, landscape services approach in the broader sense allows to take social/cultural services better into account, which is an important aspect of spatial planning.

The planning team consider the following questions when carrying out ecosystem-based analysis:

- Are key biological diversity areas defined?

- Are land use demands defined? Are anthropogenic land uses defined?

- Is the public participation ensured?

- Are the relationships of species with ecosystems and habitats defined?

- Are landscape services of the planning area defined?

\section{Development of the Plan Decisions}

At this step, areas that should be protected, areas that should be rehabilitated and areas that are suitable for anthropogenic land uses are defined.

Several human activities can occur in or around protected areas. Some of them cause severe damage to protected areas, such as logging, poaching of protected animals, mining or encroachment by human settlements. Therefore, while developing plan decisions, key ecosystems and the areas that are in interaction with them, need to be protected from the threats humans may pose. Also, the areas that have already been altered should be defined, and planning decisions for the rehabilitation of those areas and to prevent existing threats should be developed. Areas suitable for anthropogenic land use should be defined to steer lower level plans. Key performance indicators should also be defined at this step, for the monitoring and evaluation step (Fig. 8).

The planning team consider the following questions when developing plan decisions:

- Does the plan contain decisions towards the rehabilitation of altered natural areas?

- Is the integration of the plan with local plans ensured?

\section{Preparing the Draft Plan}

The draft plan -accompanied by a written statement and relevant maps-, is subject to a consultation period, during which stakeholders' opinions and comments are received and assessed. Following the assessment of opinions and comments, planning team decide which opinions and comments to include, and which to leave out. If any amendment is needed, then planning process should return to the development of plan decisions (Fig. 8). 
The planning team should consider the following questions when preparing the draft plan:

- Is the public participation ensured?

- Does the plan protect the public interest?

\section{Approval of the Plan}

The approved plan is subject to an appeal period of 30 days. During this period, appeals against the plan can be submitted. The adopted plan is published, accompanied by an adoption statement. The adoption statement details the decisions made in respect of the recommendations contained during the appeal period and the reasons for those decisions. The statement also details the changes made to the draft plan (Fig. 8).

The decision makers should consider the following questions when approving the plan:

- Is the public participation ensured?

- Is the plan consistent with conservation legislation and policy?

\section{Implementation of the Plan}

After the publication of the plan, implementation starts. Lower level plans must follow the land use decisions and policies of the higher level plan.

\section{Monitoring and Evaluation}

At the monitoring and evaluation step, digital databases are updated, key performance indicators are used to evaluate the plan, and revision or amendments needs are determined in this direction. The effective planning system, which is non-linear and circular, reflects the dynamics of planning discipline, allowing feedback at specific steps (Fig. 8).

The planning team should consider the following questions when monitoring and evaluating the plan:

- Is the public participation ensured?

- Does the planning process include monitoring and evaluation? 
Fig. 8: Effective Spatial Planning Process in Nature Conservation in Turkey

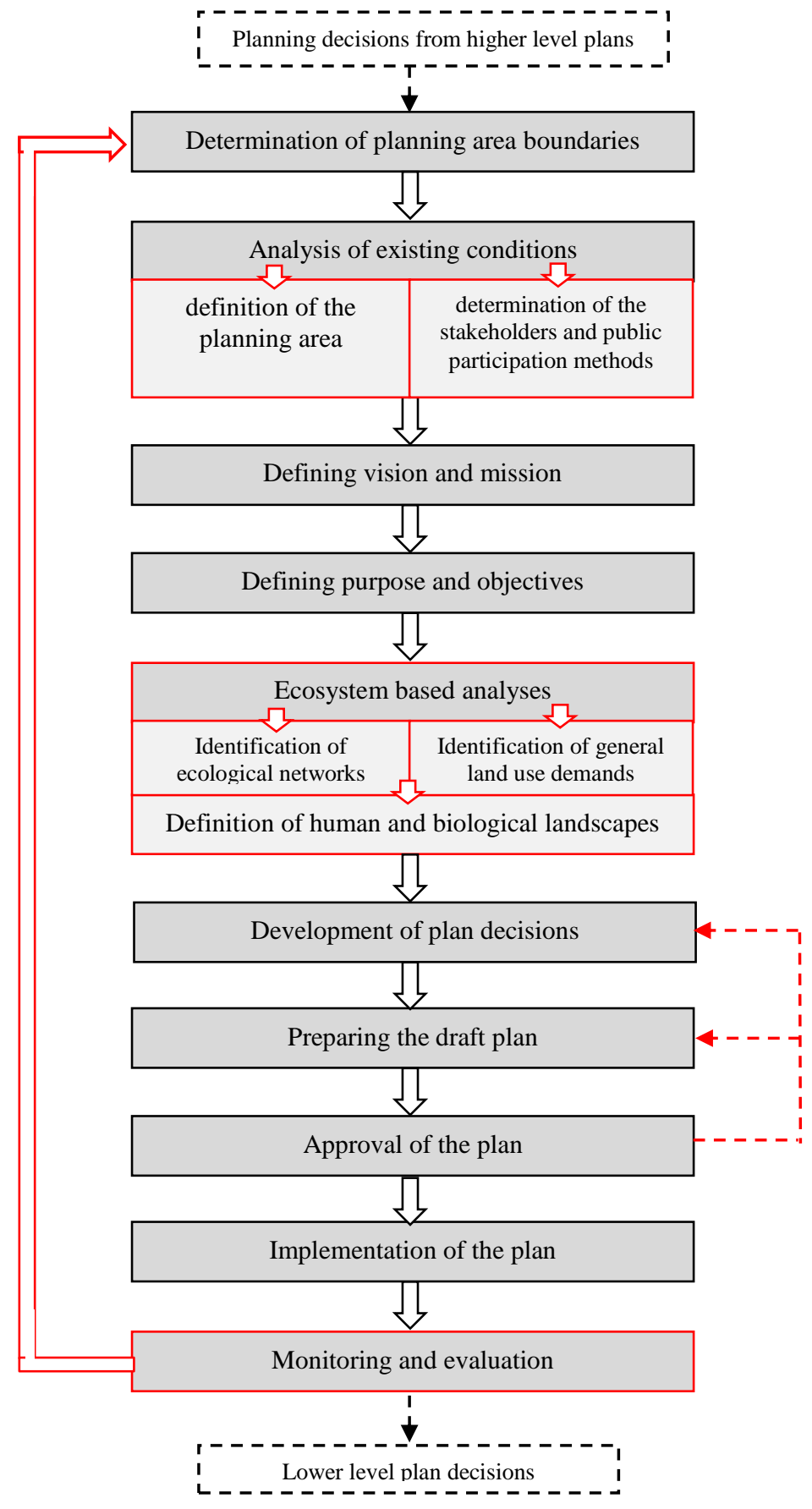


Yzici Gökmen E., Zeren Gülersoy N.: Spatial planning as a tool for effective nature conservation: A conceptual framework for Turkey's spatial planning system

\section{RESULTS AND CONCLUSION}

This study set out to determine the general principles of the conceptual framework which offers spatial planning as an effective tool to bridge the gap between land use change and nature conservation in Turkey. The literature review conducted in this context points to the conclusion that Systematic Conservation Planning, Evidence-Based Conservation Planning, Bioregional Planning and National System Planning for protected areas stand out as the preferable approaches for effective nature conservation planning. They will provide essential tools for effective spatial planning in nature conservation. That is, Systematic Conservation Planning helps to address protected areas both at regional and at national levels, while Evidence-Based Conservation Planning uses scientific data in nature conservation process. However, the mechanisms for the effective use of these data by decision makers still need to be improved. For instance, Evidence-Based Conservation Planning provides a framework to develop such mechanisms, and Bioregional Approach is applicable not only at the site level but also at national and even at international level. The latter also addresses protected areas together with their surroundings and enables the conservation actions to be implemented outside the boundaries of protected areas. In this respect, National System Planning describes a general framework for management plans at the site level, while management plans should be responsible for the integration of national, regional and local government policies, the elimination of local conflicts, management programs, and zoning control.

The results of the evaluation of Turkey's current planning system according to the conceptual framework indicate that there are two main differences between the current planning system and the conceptual framework. First, current planning system in Turkey does not include an ecosystem-based analyses step. Ecosystem-based analyses are crucial to develop land use decisions because the sustainability of a place depends mainly on its component's spatial arrangement and management (Opdam et al., 2018). According to the current planning system in Turkey, plan decisions are developed based on analyses regarding current situation of the planning area and related institutions' data and opinions. Since mostly, the drivers behind the plan decisions about land use such as power plants or transportation projects which have substantial negative impacts on ecosystems, are fuelled by the economic process at the national level, spatial planning process at regional or landscape levels do not integrate those decisions with spatial pattern and process. Whereas ecosystem-based analyses define the spatial pattern and processes in the planning area, it provides the assessment of land use decisions made at a higher level or sectoral plans, according to the ecological structure of the planning area. Therefore it is possible to integrate ecological interactions with social and economic values and also with governance systems across multiple scales (Padt et al. 2014; Nash et al. 2014). Ecosystem-based analyses also give an opportunity to assess land use demands with the natural landscape of the planning area. Such an assessment leads to define areas that should be protected, areas that should be rehabilitated and areas that are suitable for anthropogenic land uses. This approach contributes integrating protected areas with their surroundings, while current planning system causes protected areas becoming isolated landscapes. Apart from habitat loss and fragmentation, isolation is one of the main reasons for alteration the processes and functions of ecosystems (Groffman et al., 2014).

Second, the conceptual framework, unlike the current planning system in Turkey, emphasises non-linear characteristic of the planning system. In this context, monitoring and evaluation step is essential to ensure the continuity of effectiveness of spatial planning (Cullingworth \& Caves, 2013). Therefore, the conceptual framework includes defining key performance indicators at the development of the plan decisions step, which the current 
planning system does not. In this context, in a developing country like Turkey, spatial planning system which identifies the planning area with all its spatial pattern and process, develops land use decisions through ecosystem-based analyses and monitors and evaluates whether they are meeting conservation objectives, is an effective tool for nature conservation. Given that one of the most critical threats to ecosystems' sustainability and biological diversity is anthropogenic land use change, effective spatial planning will also help to achieve the goal of conservation of biological diversity.

An effective planning system for natural protected areas to be developed for Turkey, within the context of sustainability of protected areas, should be a holistic, target-oriented system defining the spatial planning process for protected areas. The spatial planning system to be developed in this context is also used by decision-makers in evaluating the ecological effectiveness of existing plans. Further researches should be done to define the criteria and indicators of the effective planning system and to determine a method to evaluate the existing plans according to the effective planning system.

\section{REFERENCES}

Bastian, O., Grunewald, K., Syrbe, R.U., Walz, U. \& Wende, W. (2014). Landscape services: the concept and its practical relevance. Landscape Ecology. 29(9), 1463-1479. DOI: 10.1007/s10980-014-0064-5.

Bosso, L., Rebelo, H., Garonna, A.P. \& Russo, D. (2013). Modelling geographic distribution and detecting conservation gaps in Italy for the threatened beetle Rosalia Alpina. Journal for Nature Conservation. 21(2), 72-80. DOI: https://doi.org/10.1016/j.jnc.2012.10.003.

Bürgi, M., Bieling, C., von Hackwitz, K., Kizos, T., Lieskovsky, J., Martin, M.G., Printsmann, A. (2017). Processes and driving forces in changing cultural landscapes across Europe. Landscape Ecology. 32(11), 2097-2112. DOI: https://doi.org/10.1007/s10980-017-0513-z

Cardinale, B.J., Duffy, J.E., Gonzalez, A., Hooper, D.U., Perrings, C., Venail, P., Naeem, S. (2012). Biodiversity loss and its impact on humanity. Nature. 486(7401), 59-67. DOI: 10.1038/nature11148.

Castella, J.C.; Bourgoin, J.; Lestrelin, G.; Bouahom, B. (2014). A model of the science-practice-policy interface in participatory land-use planning: Lessons from Laos. Landsc. Ecol. 29, 1095-1107.

Ceballos, G., Ehrlich, P. R., Barnosky, A. D., Garcia, A., Pringle, R. M. \& Palmer, T. M. (2015). Accelerated modern human-induced species losses: Entering the sixth mass extinction. Science Advances. 1(5), e1400253. DOI: 10.1126/sciadv.1400253.

Cook, H., Benson, D. \& Couldrick, L. (2016). Partnering for bioregionalism in England: a case study of the Westcountry Rivers Trust. Ecology and Society 21(2):38. DOI: http://dx.doi.org/10.5751/ES-08504-210238.

Cullingworth, B.J.; Caves, R. (2013). Planning in the USA: Policies, Issues, and Processes. Routledge: London, UK; New York, NY, USA.

Çağatay, A., Terzioğlu, E., Ekmen, Z.İ. \& Erdoğan, E. (2013). Biyolojik Çeşitliliği İzleme ve Değerlendirme Raporu. Ankara: Doğa Koruma ve Milli Parklar Genel Müdürlüğü.

Çepel, N. (2003). Ekolojik Sorunlar ve Çözümleri. Ankara: TÜBİTAK.

Davey, A.G. (1998). National system planning for protected areas. UK: IUCN, Gland, Switzerland, and Cambridge, UK. 
Yzici Gökmen E., Zeren Gülersoy N.: Spatial planning as a tool for effective nature conservation: A conceptual framework for Turkey's spatial planning system

David, M.E., David, F.R. \& David, F.R. (2014). Mission Statement Theory and Practice: A Content Analysis and New Direction. International Journal of Business. 7(1), 95-110.

Davis M., Naumann S., McFarland K., Graf A., \& Evans; D. (2014). Literature Review, the ecological effectiveness of the Natura 2000 Network. Paris: European Topic Centre on Biological Diversity. (ETC/BD Technical paper $N^{\circ}$ 5/2014)

DeFries, R., Karanth, K.K. \& Pareeth, S. (2010). Interactions between protected areas and their surroundings in human-dominated tropical landscapes. Biological Conservation. 143(12), 2870-2880. DOI: https://doi.org/10.1016/j.biocon.2010.02.010.

De Groot, R.S., Wilson, M.A. \& Boumans, R.M.J. (2002). A typology for the classification, description, and valuation of ecosystem functions, goods, and services. Ecological Economics 41(3): 393-408. DOI: https://doi.org/10.1016/S0921-8009(02)00089-7.

Doko T. \& Chen W. (2012). Ecological Networks for Biodiversity Conservation: Theory and Practice. In R. L. Nelson \& J. F. Carter (Eds.), Biodiversity Conservation: New Research (pp.1-26). Hauppauge, N.Y.: Nova Science Publishers, Inc.

Dudley, N. (Editor) (2008). Guidelines for Applying Protected Area Management Categories. Gland, Switzerland: IUCN

Dudley, N., Mulongoy, K.J., Cohen, S., Stolton, S., Barber, C.V., Gidda, S.B., (2005). Towards effective protected area systems. An action guide to implement the Convention on Biological Diversity Programme of Work on Protected Areas. Montreal: Secretariat of the Convention on Biological Diversity (Technical Series no. 18)

Ekroos, J., Leventon, J., Fischer, J., Newig, J. \& Smith, H.G. (2017). Embedding Evidence on Conservation Interventions Within a Context of Multilevel Governance. Conservation Letters. 10(1), 139-145. DOI: 10.1111/conl.12225

Gardner, L. (2002). A management framework for a system of marine protected areas for the U.S. Virgin Islands. The University of the Virgin Islands and Department of Planning and Natural Resources. USVI.

General Directorate of Nature Conservation and National Parks. (2016). Official Statistics. Retrieved March 5, 2017 from: http://www.milliparklar.gov.tr/resmiistatistikler

Glaser, M., Krause, G., Ratter, B. \& Welp, M. (2008): Human-Nature Interaction in the Anthropocene - Potential of Social-Ecological Systems Analysis. Gaia-Ecological Perspectives for Science and Society. 17(1), 77-80. DOI: https://doi.org/10.14512/ gaia.17.1.18.

Groffman, P. M., Cavender-Bares, J., Bettez, N. D., Grove, J. M., Hall, S. J., Heffernan, J.B., Steele, M.K. (2014). Ecological homogenization of urban USA. Frontiers in Ecology and the Environment. 12(1), 74-81. DOI: http://dx.doi.org/10.1890/120374.

Groves, C.R., Jensen, D.B., Valutis, L.L., Redford, K.H., Shaffer, M.L., Scott, J.M., Anderson, M.G. (2002). Planning for biodiversity conservation: Putting conservation science into practice. BioScience. 52(6), 499-512. DOI: https://doi.org/10.1641/0006-3568(2002)052[0499:PFBCPC]2.0.CO;2.

Hansen, A.J. \& DeFries, R. (2007). Ecological mechanisms linking protected areas to surrounding lands. Ecological Applications. 17(4), 974-988. DOI: 10.1890/05-1098

Hanski, I., (2001). Spatially realistic theory of metapopulation ecology. Naturwissenschaften. 88(9), 372-381. DOI: 10.1007/s001140100246

Head, B. (2008). Three lenses of evidence-based policy. Australian Journal of Public Administration. 67(1), 1-11, DOI: 10.1111/j.1467-8500.2007.00564.x. 
Hersperger, A.M., Gennaio, M.P., Verburg, P.H. \& Bürgi, M. (2010). Linking land change with driving forces and actors: four conceptual models. Ecology and Society. 15(4). URL: http://www.ecologyandsociety.org/vol15/iss4/art1/.

Hogl, K., Kvarda, E., Nordbeck, R. \& Pregernig, M. (2012). Environmental Governance The Challenge of Legitimacy and Effectiveness. Cheltenham: Edward Elgar Publishing.

Hsu, A. et al. (2016). 2016 Environmental Performance Index. New Haven, CT: Yale University.

Jongman, R.H.G. (2004). The context and concept of ecological networks. In Jongman, R.H.G. \& Pungetti, G. (Eds.), Ecological networks and greenways: concept, design, implementation (pp. 7-33). Cambridge, United Kingdom: Cambridge University Press.

Kukkala, A.S. \& Moilanen, A. (2013). Core concepts of spatial prioritisation in systematic conservation planning. Biological Reviews. 88(2), 443-464. DOI: 10.1111/brv.12008.

Kuvan, Y., Yurdakul Erol, S., Yıldırım, H.T. (2011). The general characteristics and main problems of national parks in Turkey. African Journal of Agricultural Research. 6(23), 5377-5385. DOI: 10.5897/AJAR11.377.

Levins, R. (1969). Thermal acclimation and heat resistance in Drosophila species. The American Naturalist. 103(933), 483-499. URL: http://www.jstor.org/stable/2459410.

Lin, B.B. (2011). Resilience in Agriculture through Crop Diversification: Adaptive Management for Environmental Change. Bioscience. 61, 183-193.

MacArthur, R., H. \& Wilson, E., O. (1967). The Theory of Island Biogeography, USA: Princeton University Press.

Machar, I., Vozenilek, V., Simon, J., Pechanec, V., Brus, J., Fulneček, P., Vitek, T. (2017). Joining of the historical research and future prediction as a support tool for the assessment of management strategy for European beech-dominated forests in protected areas. Nature Conservation. 22, 51-78. DOI: https://doi.org/10.3897/natureconservation.22.12902.

Margules, C.R. \& Pressey, R.L. (2000). Systematic Conservation Planning. Nature. 405, 243-253. DOI:10.1038/35012251.

Miller, K. (1996). Balancing the scales. Washington World Resources Institute.

Ministry of Environment and Forestry. (2007). The National Biological Diversity Strategy and Action Plan.

Ministry of Forestry and Water Affairs. (2013). Ministry of Forestry and Water Affairs. Retrieved 5 March 2017, from http://geodata.ormansu.gov.tr/.

Ministry of Forestry and Water Affairs. (2014). UN Convention on Biological Diversity Fifth National Report. Ankara.

Nash, K.L., Allen, C.R., Angeler, D.G., Barichievy, C., Eason, T. (2014). Discontinuities, cross-scale patterns, and the organization of ecosystems. Ecology. 95, 654-667.

Official Gazette. (2011). 648 no.lu Kanun Hükmünde Kararname.

Opdam, P., Luque, S., Nassauer, J., Verburg, P.H., Wu, J. (2018). How can landscape ecology contribute to sustainability science? Landscape Ecology. 33, 1-7. DOI: https://doi.org/10.1007/s10980-018-0610-7.

Opršal, Z., Harmáček, J., Pavlík, P., Machar, I. (2018). What Factors can Influence the Expansion of Protected Areas around the World in the Context of International Environmental and Development Goals? Problems Of Sustainable Development. 13(1), 145-157. 
Yzici Gökmen E., Zeren Gülersoy N.: Spatial planning as a tool for effective nature conservation: A conceptual framework for Turkey's spatial planning system

Padt, F., Opdam, P., Polman, N., Termee, C. (2014). Scale-sensitive governance of the environment. Wiley, Chichester.

Palomo, I., Montes, C., Martín-López, B., González, J., Garcia Llorente, M., Alcorlo, P. \& Rosario García-Mora, M. (2014). Incorporating the Social-Ecological Approach in Protected Areas in the Anthropocene. BioScience. 64(3), 181-191. DOI: 10.1093/biosci/bit033.

Peerlings, J. \& Polman, N. (2004). Wildlife and landscape services production in Dutch dairy farming; jointness and transaction costs. European Review of Agricultural Economics. 31(4), 427-449. DOI: https://doi.org/10.1093/erae/31.4.427.

Pimm, S. L., Jenkins, C. N., Abell, R., Brooks, T. M., Gittleman, J. L., Joppa, L. N., Raven, P. H., Roberts, C. M. \& Sexton, J. O. (2014). The biodiversity of species and their rates of extinction, distribution, and protection. Science. 344(6187), 987. DOI: 10.1126/science. 1246752 .

Pressey, R.L. \& Bottrill, M.C. (2009). Approaches to landscape- and seascape-scale conservation planning: convergence, contrasts and challenges. Oryx. 43(4), 464-75.

Pullin, A.S. \& Knight, T.M. (2001). Effectiveness in conservation practice: pointers from medicine and public health. Conservation Biology. 15(1), 50-54. DOI: 10.1111/j.1523-1739.2001.99499.x.

Pullin, A.S. \& Knight, T.M. (2003). Support for decision making in conservation practice: an evidence-based approach. Journal for Nature Conservation. 11(2), 83-90. DOI: https://doi.org/10.1078/1617-1381-00040.

Pullin, A.S. \& Stewart, G.B. (2006). Guidelines for systematic review in conservation and environmental management. Conservation Biology. 20(6), 1647-1656. DOI: 10.1111/j.1523-1739.2006.00485.x

Pullin, A.S., Sutherland, W., Gardner, T., Kapos, V. \& Fa, J.E. (2013). Conservation priorities: identifying a need, taking action and evaluating success. In Macdonald, D.W. \& Willis, K.J. (Eds), Key Topics in Conservation Biology 2 (pp. 3-22). John Wiley \& Sons, Ltd.

Reed, J., Vianen, J.V., Deakin, E.L., Barlow, J. \& Sunderland, T. (2016). Integrated landscape approaches to managing social and environmental issues in the tropics: learning from the past to guide the future. Global Change Biology. 22(7), 2540-2554. DOI: 10.1111/gcb.13284.

Sarkar, S. \& Illoldi-Rangel, P. (2010). Systematic conservation planning: an updated protocol. Natureza Conservaçao. 8(1), 19-26. DOI: 10.4322/natcon.00801003.

Sayer, J., Sunderland, T., Ghazoul, J., Pfund, J.1., Sheil, D., Meijaard, E., Buck, L.E. (2013). Ten principles for a landscape approach to reconciling agriculture, conservation, and other competing land uses. PNAS. 110(21), 8349-8356. DOI: 10.1073/pnas.1210595110.

Schwilch, G.; Bachmann, F.; Valente, S.; Coelho, C.; Moreira, J.; Laouina, A.; Chaker, M.; Aderghal, M.; Santos, P.; Reed, M.S. (2012). A structured multi-stakeholder learning process for Sustainable Land Management. J. Environ. Manag. 107, 52-63.

Secretariat of the Convention on Biological Diversity. (2004). The Ecosystem Approach. Montreal.

Secretariat of the Convention on Biological Diversity, (2010). Decision Adopted By The Conference of The Parties To The Convention On Biological Diversity at Its Tenth Meeting . Retrieved 5 March, 2017 from: https://www.cbd.int/doc/decisions/cop-10/cop-10Dec-02-en.pdf.

Sutherland, W.J., Pullin, A.S., Dolman, P.M. \& Knight, T.M. (2004). Response to Griffiths. 
Mismatches between conservation science and practice. Trends in Ecology \& Evolution. 19(11), 565-566. DOI: 10.1016/j.tree.2004.09.005

Syrbe, R.U. \& Walz, U. (2012). Spatial indicators for the assessment of ecosystem services: providing, benefiting and connecting areas and landscape metrics. Ecological Indicators. 21, 80-88. DOI: https://doi.org/10.1016/j.ecolind.2012.02.013.

Termorshuizen, J.W. \& Opdam, P. (2009). Landscape services as a bridge between landscape ecology and sustainable development. Landscape Ecology. 24(8), 1037-1052. DOI: http://dx.doi.org/10.1007/s10980-008-9314-8.

Théau, J., Bernier, A. \& Fournier, R.A. (2015). An evaluation framework based on sustainability-related indicators for the comparison of conceptual approaches for ecological networks. Ecological Indicators. 52, 444-457. DOI: https://doi.org/10.1016 /j.ecolind.2014.12.029.

Turak, A., Balkız, Ö., Ambarlı, D., Durmuş, M., Özkil, A., Yalçın, S., Özüt, D., Kınıkoğlu, Y., Meydan Kocaman, T., Cengiz, S., Albayrak, F., Kurt, B., Zeydanlı, U., Bilgin C. (2011). Karadeniz Bölgesi Sistematik Koruma Planlaması. Ankara. Doğa Koruma Merkezi.

Türkeş, M. (2015). Biyocoğrafya bir paleocoğrafya ve ekoloji yaklaşımı. Ankara: Kriter Yayınevi.

UNEP-WCMC and IUCN (2016). Protected Planet Report 2016. Cambridge UK and Gland, Switzerland: UNEP-WCMC and IUCN.

United Nations (2015). Sustainable Development Goals, New York

Ün, C., Cengiz, S., Çekiç, O., Karaelmas, O., Karagüllü, O., Karauz, E.S., Kocaman, T., Koray, Z., Kündük, H., Özdemir, A., Özel, N., Özüdoğru, E., Taş, S. \& Turak, A. (2009). Sistematik Koruma Planlaması Yaklaşımı: Kıyı Ege Bölgesi Örneği. Ankara Üniversitesi Çevrebilimleri Dergisi. 2(1), 55-65. DOI: 10.1501/Csaum_0000000014.

Vilhena, D.A. \& Antonelli, A. (2015). Network approach for identifying and delimiting biogeographical regions. Nature Communications. 6:6848. DOI: 10.1038/ncomms 7848 .

Watson, J. E. M. (2014). The performance and potential of protected areas. Nature. 515, 67-73. DOI: 10.1038/nature13947.

Willemen, L., Veldkamp, A., Verburg, P.H., Hein, L. \& Leemans, R. (2012). A multi-scape modelling approach for analyzing landscape service dynamics. Journal of Environmental Management. 100, 86-95. DOI: https://doi.org/10.1016/j.jenvman.2012.01.022.

Wilson, T.S., Sleeter, B.M., Sleeter, R.R. \& Soulard, C.E. (2014). Land-use threats and protected areas: a scenario-based, landscape-level approach. Land 3(2), 362-389. DOI: $10.3390 /$ land3020362.

Wu, J.G., 2013. Landscape sustainability science: ecosystem services and human well-being in changing landscapes. Landscape Ecology. 28(6), 999-1023. DOI: 10.1007/s10980-013-9894-9.

Wu, R., Long, Y., Malanson, G.P., Garber, P.A., Zhang, S., Li, D., Duo, H. (2014). Optimized Spatial Priorities for Biodiversity Conservation in China: A Systematic Conservation Planning Perspective. PLoS ONE. 9(7), e103783. DOI:10.1371/journal.pone.0103783.

\section{Web adress:}

www.politeknik.org.tr

http://www.karorsan.org.tr/images/Filyos-Vadisi.pdf 
Yzici Gökmen E., Zeren Gülersoy N.: Spatial planning as a tool for effective nature conservation: A conceptual framework for Turkey's spatial planning system

www.tema.org.tr

www.yapi.com.tr 